\title{
Leaf and root $\mathbf{C}$-to- $\mathrm{N}$ ratios are poor predictors of soil microbial biomass $\mathrm{C}$ and respiration across 32 tree species
}

\author{
Olga Ferlian ${ }^{*}, 1,2$, Christian Wirth ${ }^{1,2,3}$, and Nico Eisenhauer ${ }^{1,2}$ \\ ${ }^{1}$ German Centre for Integrative Biodiversity Research (iDiv) Halle-Jena-Leipzig, Deutscher Platz \\ 5e, 04103 Leipzig, Germany \\ ${ }^{2}$ Institute of Biology, Leipzig University, Johannisallee 21, 04103 Leipzig, Germany \\ ${ }^{3}$ Max-Planck-Institute for Biogeochemistry, Hans-Knöll-Straße 10, 07745 Jena, Germany
}

\begin{abstract}
Soil microorganisms are the main primary decomposers of plant material and drive biogeochemical processes like carbon and nitrogen cycles. Hence, knowledge of their nutritional demands and limitations for activity and growth is of particular importance. However, potential effects of the stoichiometry of soil and plant species on soil microbial activity and carbon use efficiency are poorly understood. Soil properties and plant traits are assumed to drive microbial carbon and community structure. We investigated the associations between $\mathrm{C}$ and $\mathrm{N}$ concentrations of leaf, root, and soil as well as their ratios and soil microbial biomass $\mathrm{C}$ and activity (microbial basal respiration and specific respiratory quotient) across 32 young native angiosperm tree species at two locations in Central Germany. Correlations between C:N ratios of leaves, roots, and soil were positive but overall weak. Only regressions between root and leaf C:N ratios as well as between root and soil C:N ratios were significant at one site. Soil microbial properties differed significantly between the two sites and were significantly correlated with soil $\mathrm{C}: \mathrm{N}$ ratio across sites. Soil $\mathrm{C}$ concentrations rather than $\mathrm{N}$ concentrations drove significant effects of soil C:N ratio on soil microbial properties. No significant correlations between soil microbial properties and leaf as well as root $\mathrm{C}: \mathrm{N}$ ratios were found. We found weak correlations of $\mathrm{C}: \mathrm{N}$ ratios between plant aboveground and belowground tissues. Furthermore, microorganisms were not affected by the stoichiometry of plant tissues in the investigated young trees. The results suggest that soil stoichiometry represents a consistent determinant of soil microbial biomass and respiration. Our study indicates that stoichiometric relationships among tree organs can be weak and poor predictors of soil microbial properties in young tree stands. Further research in controlled experimental settings with a wide range of tree species is needed to study the role of plant chemical traits like the composition and stoichiometry of root exudates in determining interactions between above- and belowground compartments.
\end{abstract}

\section{Keywords}

Deciduous trees; plant chemistry; roots; soil chemistry; soil microbial biomass; stoichiometry

\footnotetext{
*Corresponding author: Olga Ferlian, olga.ferlian@idiv.de; Phone: +49 34133173.
} 


\section{Introduction}

Concerns about the consequences of climate change for the structure and functioning of ecosystems have evoked substantial scientific interest in biogeochemical processes in terrestrial ecosystems in the last few decades (e.g., Schimel, 1995; Lal, 2004; Luo et al., 2004; Chaopricha and Marin-Spiotta, 2014). Despite the consensus that soil processes play a key role in biochemical cycles, the driving forces of soil microorganisms and their functions are not well understood. Carbon (C) and nitrogen $(\mathrm{N})$ cycles are driven by microorganisms being the main primary decomposers in soil (Swift et al., 1979). Hence, it is crucial to understand their nutritional demands and limitations for activity and growth (de Ruiter et al., 1993; Hanson et al., 2000; Bradford et al., 2013; Buchkowski et al., 2015).

Organisms depend on particular nutrients for their metabolic pathways (e.g., $\mathrm{N}$ for protein biosynthesis) and the restrictions the environment exerts to nutrient availability. The nutrient with the lowest availability compared to the organism's demand limits cell growth and reproduction (von Liebig, 1840). For decades, it has been assumed that soil microorganisms are limited by $\mathrm{C}$ availability rather than $\mathrm{N}$, phosphorus (P), or potassium (Wardle, 1992; Vance and Chapin, 2001; Hobbie and Hobbie, 2013; Farrell et al., 2014). However, this view has been questioned as soils comprise up to 100 times more dead organic $\mathrm{C}$ compared to microbial biomass (Vance and Chapin, 2001; Xu et al., 2013). Several studies found N- and also P-limitation in soil microorganisms (Scheu and Schaefer, 1998; Chen and Stark, 2000; Hartman and Richardson, 2013). In a global study, Hartman and Richardson (2013) found both $\mathrm{C}$ and $\mathrm{N}$ to limit microbial biomass growth, with effects of $\mathrm{C}$ being comparably weaker. Recent studies support the idea that availability of $\mathrm{C}$ and $\mathrm{N}$ in soil and, thus, possible $\mathrm{C}$ - and $\mathrm{N}$-limitation are closely linked due to physical associations between both elements in soil (Vance and Chapin, 2001; Hartman and Richardson, 2013).

To compensate low availability of either $\mathrm{C}$ or $\mathrm{N}$, organisms take up resources in excess and release the other element in form of overflow respiration ( $\mathrm{C}$ excess) or ammonium ( $\mathrm{N}$ excess), which leads to reciprocal impacts on element availability in soil (Tempest and Neijssel, 1992; Schimel and Weintraub, 2003). Consequently, there is an apparent need for considering the interplay between both elements, e.g., as element ratios, in studies dealing with nutritional demands of microorganisms (Myrold, 1999; Cleveland and Liptzin, 2007; Demoling et al., 2007; Wan et al., 2015). The concept of ecological stoichiometry, originating from aquatic ecosystems, considers the balance of multiple elements in an ecological context (Elser et al., 2000).

Plant leaf and root tissues have equivalent functions in the soil system representing the base material for microbial decomposition and recycling of nutrients to the plant. Furthermore, their functions also inherently depend on each other as, e.g., roots take up water, N, and metal-ions that are crucial for photosynthetically active parts (leaves), whereas leaves deliver $\mathrm{C}$ to the roots. This leads to an interrelationship between leaf and root tissue traits, e.g., in growth rates, specific leaf area/specific root length, life span, and respiration (King et al., 2002; Freschet et al., 2010, 2013; Birouste et al., 2012; Reich, 2014). A multitude of studies across different plant types and terrestrial ecosystems showed that particularly $\mathrm{N}$ contents in plant leaf and root tissue are correlated (Craine et al., 2005; Hobbie et al., 2010; Reich, 
2014). However, relationships among plant tissue traits were also disproved in the context of tissue longevity, decomposition rates, and other elements (Hobbie, 2008; Hobbie et al., 2010; Hajek et al., 2013). Hobbie et al. (2010) advocate that different environmental conditions above- and belowground may lead to decoupling of root and leaf traits, such as chemical composition of tissues. However, investigating relationships among plant traits, especially that of plant chemical composition, calls for highly controlled experimental settings where individuals are clearly isolated, especially belowground. To date, studies often lack this control leading to idiosyncrasies of results. Furthermore, to infer global patterns of elemental correlations as well as patterns on a fine taxonomic resolution, strong gradients in plant stoichiometry and a wide range of species are needed.

Plant traits are known to affect soil microbial $\mathrm{C}$ and community structure as microorganisms inherently rely on organic compounds provided by plants (leaf and root tissue). Plants, in turn, rely on inorganic compounds provided mainly by the enzyme activities of microorganisms (Hinsinger et al., 2009; Lambers et al., 2009; Zechmeister-Boltenstern et al., 2015). Beside the input of leaf litter, input of root litter and rhizodeposits play a major role in fuelling soil organisms and processes and consequently in driving the elemental composition of soil (Pollierer et al., 2007; Eisenhauer and Reich, 2012). Particularly studies in forests have shown that root inputs to the soil shape nutritionally distinct microenvironments (that may lead to stoichiometric relationships between plants and soil) and hotspots of microbial activity in the rhizosphere of plants (Paterson, 2003; Wardle et al., 2004; Pollierer et al., 2007; Hinsinger et al., 2009; Wang et al., 2013). This was found to result in correlations between the stoichiometries of soil microorganisms and different plant tissues (Martiny et al., 2006; Fanin et al., 2013). However, it is far less well understood whether such relationships are generalisable across many plant species (Bell et al., 2014).

It is, therefore, reasonable to assume that processes in plant roots, microorganisms, and rootassociated soil are closely related as soil microorganisms feed back on plant and soil C and nutrient compositions, and all three respond to environmental factors (Wardle et al., 2004; van der Heijden et al., 2008; de Vries et al., 2012). These relationships may preferably apply to chemical traits, such as $\mathrm{C}$ and $\mathrm{N}$ concentrations and $\mathrm{C}: \mathrm{N}$ ratios.

In the present study, we investigated associations between leaf, root, and soil $\mathrm{C}$ and $\mathrm{N}$ concentrations and soil microbial biomass $\mathrm{C}$ and respiration across 32 native angiosperm tree species spanning a wide stoichiometric gradient at two locations of differing soil type in central Germany. We hypothesised that (1) due to correlations of traits between tree leaf and root tissue, $\mathrm{C}: \mathrm{N}$ ratios of these are correlated as well; (2) trees and soil are in close exchange of $\mathrm{C}$ and nutrients and, therefore, affect each other being reflected by a correlation between $\mathrm{C}: \mathrm{N}$ ratios of plant tissues (leaves and roots) and soil; (3) $\mathrm{C}: \mathrm{N}$ ratios in plant tissues (leaves and roots) and soil drive soil microbial biomass and respiration as soil microorganisms mediate $\mathrm{C}$ and nutrient provision between trees and soil. 


\section{Materials and methods}

\section{Study sites}

The study was conducted at two sites in central Germany with contrasting characteristics. One site is dominated by agricultural fields and located in Bad Lauchstädt (Saxony-Anhalt; $5124^{\prime} \mathrm{N}, 1153^{\prime} \mathrm{E}$, in the following referred to as 'observational site') at $114 \mathrm{~m}$ a.s.l., characterised by a continental climate with a mean annual precipitation of $484 \mathrm{~mm}$ and a mean annual temperature of $8.8^{\circ} \mathrm{C}$ (Altermann et al., 2005). The soil type is classified as Haplic Chernozem developed from loess with a $\mathrm{pH}$ of 7.6. Distance between sampled trees ranged from 5 to $500 \mathrm{~m}$. Focal trees were interspersed with single common ash (Fraxinus excelsior L.) and maple trees (Acer campestre L., A. platanoides L., and A. pseudoplatanus L.) as well as European raspberry (Rubus idaeus L.) and Rosa canina L. Most trees grow on successional urban areas, are self-seeded, and had ages between ten and 25 years at time of sampling.

The second site is the ARBOfun functional diversity arboretum located $13 \mathrm{~km}$ south-west from Leipzig (Saxony, Germany; 51 $16^{\prime} \mathrm{N}, 12^{\circ} 30^{\prime} \mathrm{E}$, in the following referred to as 'arboretum') at $150 \mathrm{~m}$ a.s.l. in a maritime-continental transitional climate zone with a mean annual precipitation of $516 \mathrm{~mm}$ and a mean annual temperature of $8.4^{\circ} \mathrm{C}$. The soil type is classified as Luvisol formed by loess with a $\mathrm{pH}$ of 5.7. The site is a former extensively used arable field. At the arboretum, distance between focal trees was between 5.8 and $80 \mathrm{~m}$. The site is mown regularly and is dominated by small herbs and grasses, such as Arrhenatherum elatius L., Artemisia vulgaris L., Poa sp. L., Reseda luteola L., Symphytum officinale L., and Verbascum sp. L. All trees were planted in March 2012 and had an age of five years at time of sampling.

\section{Sampling of leave, root, and soil material}

Common native angiosperm trees of an age between five and 15 years were sampled at the two sites in July 2014. At the arboretum, the following 32 tree species were sampled (five replicates of each): Acer campestre L., A. platanoides L., A. pseudoplatanus L., Aesculus hippocastanum L., Betula pendula Roth, Carpinus betulus L., Fraxinus excelsior L., Juglans regia L., Populus nigra L., Prunus avium L., Quercus robur L., Robinia pseudoacacia L., Sorbus aucuparia L., Tilia cordata Mill., Ulmus minor Mill., Alnus glutinosa L. Gaertn., A. incana L. Moench, B. pubescens Ehrh., Fagus sylvatica L., Malus sylvestris L. Mill., P. tremula L., P. padus L., Q. petraea (Mattuschka) Liebl., Q. rubra L., Salix alba L., S. caprea L., $S$. aria (L.) Crantz, S. domestica L., S. torminalis (L.) Crantz, T. platyphyllos Scop., $U$. glabra Huds., and $U$. laevis Pall. At the observational site, the first 15 tree species were sampled (five replicates of each) representing local deciduous tree species diversity. For analyses of $\mathrm{C}$ and $\mathrm{N}$ concentrations in leaves, five to 20 vital, intact, and mature sun leaves were collected from different branches of each tree, stored in paper bags, and cooled subsequently until further processing.

For analyses of $\mathrm{C}$ and $\mathrm{N}$ in fine roots, a hole was dug close to the base of each target tree where density of herbaceous roots was low due to paperboard collars installed around the tree base to reduce weed growth close to trees. Tree roots that were connected to the tree 
were tracked to fine root level. Roots with sufficient amounts of fine roots were cut and stored in self-sealing plastic bags in a cool box until further processing. In addition, about $200 \mathrm{~g}$ of soil was taken from the root zone of each tree at a depth of $0-10 \mathrm{~cm}$ for analyses of soil $\mathrm{C}$ and $\mathrm{N}$ concentrations and soil microbial properties. Special care was taken to sample only soil material in the direct vicinity of the roots as root putative effects on soil microorganisms are likely to decrease with increasing distance to roots.

\section{Carbon and nitrogen concentrations in leaves, fine roots, and soil}

Roots were washed in hand-hot water to remove attached soil particles and other material, rinsed with deionised water and transferred into paper bags. Leave, fine root, and soil samples were dried at $60^{\circ} \mathrm{C}$ for $72 \mathrm{~h}$. First- and second-order roots of each root sample were cut off with scissors and used for analyses (after Pregitzer et al., 2002). Fine roots were ground manually, leaves (without petiole and rachis) and soil were ground with a ball mill (Cornelissen et al., 2003), subsequently dried for another $24 \mathrm{~h}$, and transferred into tin capsules for $\mathrm{C}$ and $\mathrm{N}$ analyses. Analyses were performed using an elemental analyser (Vario EL II, Elementar Analysensysteme GmbH, Hanau, Germany). C and $\mathrm{N}$ concentration is given as relative mass proportion of the element (in \%) per sample mass. C:N ratio was calculated from $\mathrm{C}$ and $\mathrm{N}$ mass proportions.

\section{Soil microbial properties}

For measurements of microbial basal respiration, microbial biomass $\mathrm{C}$, and specific respiration, subsamples of soil were sieved ( $2 \mathrm{~mm}$ mesh) to remove roots and stones as well as for homogenisation (Anderson and Domsch, 1978). Five $\mathrm{g}$ of soil (fresh weight) per sample were analysed using an $\mathrm{O}_{2}$-microcompensation apparatus (Scheu, 1992). Further, gravimetric soil water content was determined. The microbial respiratory response was measured in intervals of one hour for $24 \mathrm{~h}$ at $20^{\circ} \mathrm{C}$. For calculations of substrate-induced respiration, the respiratory response to addition of D-Glucose was measured ( $8 \mathrm{mg} \mathrm{g}^{-1}$ dry weight, in $400 \mu$ deionised water). The maximum initial respiratory response (MIRR, in $\mu \mathrm{l}$ $\mathrm{O}_{2} \mathrm{~h}^{-1} \mathrm{~g}^{-1}$ soil dry weight) was calculated as the mean of the first three hours after the first peak caused by the disturbance of soil during preparations. Microbial biomass $\left(\mathrm{C}_{\mathrm{mic}}\right.$, in $\mu \mathrm{g} \mathrm{C}$ $\mathrm{g}^{-1}$ soil dry weight) was calculated as $38 \times$ MIRR (Beck et al., 1997). Specific respiration quotient was calculated dividing basal respiration by microbial biomass.

\section{Statistical analyses}

To improve homoscedasticity and normal distribution, all data were log-transformed. C:N ratios of leaves, roots, and soil were compared among tree species at the two sites using general linear model (separate models for the two sites). Linear mixed effects analyses (Random slope models) of $\mathrm{C}$ and $\mathrm{N}$ concentrations and of $\mathrm{C}: \mathrm{N}$ ratios of tree species at the two sites were employed to test for correlations between $\mathrm{C}: \mathrm{N}$ ratios of specific compartments (leaves, roots, and soil). Tree species was used as random factor. For the inspection of general relationships among compartments across sites, we conducted regressions between sites with slopes of regressions between compartments. Analyses of microbial properties between sites, species and regressions with $\mathrm{C}$ concentrations, $\mathrm{N}$ concentrations, and $\mathrm{C}: \mathrm{N}$ ratio were conducted using linear mixed effects analyses (random intercept models) with all former variables as fixed factors and gravimetric soil water 
content as random factor. P-values were obtained using Likelihood ratio tests (full model against the model without the effect in question). Marginal R-squares were obtained using the r.squaredGLMM function within the R-package MuMIn. ANOVAs were conducted using STATISTICA 12 for Windows (StatSoft, Inc.; Tulsa, OK, USA); linear mixed effects analyses and forest plots were conducted with $\mathrm{R}$ (R Core Team, 2014) using the package Ime4 and metafor, respectively.

\section{Results}

\section{$\mathrm{C}: \mathrm{N}$ ratios in leaves, fine roots, and soil}

At the observational site, $\mathrm{C}: \mathrm{N}$ ratios of leaves, fine roots, and soil differed significantly among tree species with differences being strongest in leaves (leaves: $F_{16,52}=13.21, P<$ 0.001; fine roots: $F_{16,52}=3.08, P=0.001$; soil: $F_{16,52}=4.50, P<0.001$ ). At the arboretum, differences in $\mathrm{C}: \mathrm{N}$ ratios were significant but statistically weaker compared to the observational site (leaves: $F_{31,94}=6.22, P<0.001$; fine roots: $F_{31,94}=6.51, P<0.001$; soil: $\left.F_{31,94}=2.90, P<0.001\right)$. Leaf $\mathrm{C}: \mathrm{N}$ ratios of tree species at the two sites ranged between 14.3 and 43.9 (arboretum: Fig. 1; observational site: Supplementary material, Fig. A.1). Overall, leaf C:N ratios at the observational site were higher compared to those at the arboretum. In general, the Alnus and Tilia species and $R$. pseudoacacia had consistently low leaf C:N ratios, whereas the Sorbus species and A. hippocastanum had consistently high ones.

Root C:N ratios of tree species at the two sites ranged between 17.0 and 63.6 with the Alnus species, $R$. pseudoacacia, F. excelsior, and J. regia having consistently lowest C:N ratios, whereas the Salix species had the highest root C:N ratios. All other species did not follow a consistent pattern.

Soil C:N ratios differed only little among tree species and ranged between 11.9 and 17.6. Root C:N ratios of tree species corresponded more strongly with leaf C:N ratios compared to soil C:N ratios (compare black, grey, and white bars in Fig. 1a, b, and c, respectively).

Correlations between C:N ratios of leaves, roots, and soil were slightly positive but overall weak (Table 1, Fig. 2). Only regressions between root and leaf C:N ratios as well as between root and soil $\mathrm{C}: \mathrm{N}$ ratios in the arboretum were significant $\left(\chi^{2}(1)=4.52, P=0.03\right.$ and $\chi^{2}(1)$ $=5.62, P=0.02$, respectively). Significant regressions of C:N ratios were determined by $\mathrm{N}$ concentrations rather than by $\mathrm{C}$ concentrations (Table 1). Regressions between leaf and soil $\mathrm{C}: \mathrm{N}$ ratios were not significant, whereas in the arboretum, that of $\mathrm{C}$ concentrations was. In models of root and leaf $\mathrm{C}: \mathrm{N}$ ratios in the arboretum, $11 \%$ of the variance in the response was explained by tree species, whereas in models of root and soil C:N ratios, $6 \%$ of the variance was explained by tree species.

Regressions between slopes of root $\mathrm{C}: \mathrm{N} \sim$ leaf $\mathrm{C}: \mathrm{N}$ ratios $\left(\mathrm{R}^{2}=0.06\right)$ as well as of root $\mathrm{C}: \mathrm{N} \sim$ soil $\mathrm{C}: \mathrm{N}$ ratios $\left(\mathrm{R}^{2}=0.27\right)$ between the two sites indicated weak patterns across sites, whereas that of leaf $\mathrm{C}: \mathrm{N} \sim$ soil $\mathrm{C}: \mathrm{N}$ ratio $\left(\mathrm{R}^{2}<0.01\right)$ was absent. 


\section{Soil microbial properties}

Microbial basal respiration, microbial biomass, and specific respiratory quotient differed significantly between the two sites $\left(\chi^{2}(1)=13.90, P<0.001 ; \chi^{2}(1)=51.24, P<0.001\right.$; $\chi^{2}(1)=16.31, P<0.001$, respectively; Table 2$)$. Microbial basal respiration and microbial biomass were considerably higher at the observational site than at the arboretum $(+12 \%$ and $+92 \%$, respectively); the specific respiratory quotient differed slightly but significantly between sites $(-0.002 \%)$. In contrast, basal respiration and microbial biomass did not differ between tree species, whereas the specific respiratory quotient did (Table 2).

\section{Soil microbial properties and element concentrations in leaves, fine roots, and soil}

All soil microbial properties were significantly correlated with soil $\mathrm{C}: \mathrm{N}$ ratio across sites (BAS: $\chi^{2}(1)=16.67, P<0.001 ; \mathrm{C}_{\text {mic }}: \chi^{2}(1)=37.24, P<0.001 ; \mathrm{qO} 2: \chi^{2}(1)=11.87, P<$ 0.001 ; Table 2, Fig. 3). Generally, relationships were stronger in the arboretum than at the observational site. Significant effects were stronger for basal respiration and microbial biomass (positive correlations in both cases) compared to specific respiratory quotient (negative correlation; Fig. 3). Although mostly not significant, results indicate that soil C concentrations rather than $\mathrm{N}$ concentrations determined significant effects of soil C:N ratio on soil microbial properties (Table 2). Regressions indicated no significant relationships between soil microbial properties and leaf as well as root $\mathrm{C}$ : N ratios (both $\mathrm{R}^{2} \leq 0.01$ ).

\section{Discussion}

We investigated correlations of $\mathrm{C}$ and $\mathrm{N}$ concentrations as well as of $\mathrm{C}: \mathrm{N}$ ratios between soil, tree roots, and leaves. For this, we used 32 young angiosperm tree species spanning a wide stoichiometric gradient. Further, we explored relationships between $\mathrm{C}: \mathrm{N}$ ratios and microbial activity and growth. The key findings of our study are: 1) correlations of $\mathrm{C}$ and $\mathrm{N}$ between above- and belowground plant compartments were overall weak across species; 2) root and soil C:N ratios were correlated, but correlations were weak; 3) soil microbial activity and growth were related to soil $\mathrm{C}: \mathrm{N}$ ratio, but not to that of any plant tissue.

\section{Correlation of $\mathrm{C}: \mathrm{N}$ ratios in leaves and roots}

$\mathrm{C}: \mathrm{N}$ ratios of plant compartments and soil differed significantly among tree species at both sites. Overall, $R$. pseudoacacia and the Alnus species had comparably low leaf and root C:N ratios, while other species did not show any consistent patterns. Both genera commonly associate with $\mathrm{N}$-fixing bacteria that allocate more $\mathrm{N}$ to plant tissues compared to other tree species. Furthermore, these species have higher growth rates being typically related to higher $\mathrm{P}$ but also higher $\mathrm{N}$ concentrations (Elser et al., 2000).

Tree leaf C:N ratios were lower than root C:N ratios across both sites (14.3-43.9 and 17.0-63.6, respectively). In line with our results, Newman and Hart (2006) reported N concentrations to be higher in leaf compared to root tissue across different forest biomes. Jackson et al. (1997) found C:N ratios of fine roots to be around 41, which is in line with our findings (mean: $42.8 \pm 9.8$ ). Overall, chemical composition and, thus, decomposition rates may differ between tree leaves and roots due to fundamentally different physiological functions (Silver and Miya, 2001; Cusack et al., 2009). Furthermore, leaves, as 
photosynthetically active plant organs, represent a $\mathrm{C}$ source and the main compartment for carbohydrate synthesis. For plants, it is crucial to allocate the most limiting resources in this organ, such as N, to maximise energy gain (Newman and Hart, 2006). In plant fine roots, C is allocated in excess and released as rhizodeposits presumably adding to these differences in $\mathrm{C}: \mathrm{N}$ ratios.

Tree leaf C:N ratios were related to that of tree roots, but relationships were overall weak at the arboretum. At the observational site, correlations were even absent indicating weak relationships of plant C:N ratios among tree compartments. Similarly, in a study with the same angiosperm trees in the arboretum, correlations of C:N between leaves and roots were also found to be weak (C. Wirth, pers. comm.). This is in contrast to other studies where tree leaf and root elemental content and ratios were highly correlated (Craine et al., 2005; Tjoelker et al., 2005; Newman and Hart, 2006). One of the reasons for this discrepancy could be the young age of the sampled trees in our study. Due to their low biomass, immature trees may experience lower competition for nutrients with other organisms and, thus, lower nutrient limitation. This may lead to less efficient nutrient allocation that is independent of nutrient absorption processes in the different tissues compared to mature trees (Osone and Tateno, 2005; Maire et al., 2009). In fact, Newman and Hart (2006) found that with higher nutrient availability relationships between leaf and root $\mathrm{C}: \mathrm{N}$ ratios become weaker, which may be the case for the fertile Chernozem soils at the observational site.

The weak correlation of $\mathrm{C}: \mathrm{N}$ ratios in leaves and roots found here was rather driven by $\mathrm{N}$ than by $\mathrm{C}$ concentrations. $\mathrm{N}$ is comparably more limiting in plants (Vitousek et al., 1997), and $\mathrm{N}$-uptake via roots and, thus, $\mathrm{N}$ concentrations in roots determine the assimilation of $\mathrm{N}$ processing tissues. Tree species explained only a small proportion of the overall variance in leaf and root $\mathrm{C}: \mathrm{N}$ ratio regressions, indicating that the lack of relationships between tree leaf and root chemical composition may be generalisable across different common deciduous tree species.

\section{Effects of tree tissue chemistry on soil chemistry}

Root and soil C:N ratio in the arboretum were significantly correlated suggesting dependence between chemical composition of plant belowground tissue and soil. This is also in line with findings that belowground carbon and nutrient input to soil is mainly driven by root material and rhizodeposition in forests (Pollierer et al., 2007). However, it is still not fully explored if conclusions on chemical composition of plant litter can be drawn from chemical composition of living plant tissue. Several studies documented links between chemical composition of senescent and living tissue as chemical composition of living plant tissue determines its decomposition rates and these, further, determine chemical composition of plant litter (Aerts and Caluwe, 1997; Heal et al., 1997; Reich et al., 2005; Cortez et al., 2007). Furthermore, it is rather difficult to isolate tiny root litter fragments from the complex soil matrix in a sufficient amount for elemental analyses. Studying correlations between living plant tissues and soil is also more meaningful than between litter and soil as the state of chemical composition in the former is clearly defined and, therefore, comparable between treatments. Litter is often sampled in different states of decomposition which are hardly ascertainable. 
Moreover, a major part of the carbon and nutrient input to soil is via rhizodeposition (Hutsch et al., 2000). Rhizodeposits and root litter represent a rather poorly dispersed $\mathrm{C}$ and nutrient source, which is mainly restricted to the direct vicinity of roots. This is reflected by the significant correlation between root and soil C:N ratio in the arboretum. However, relationships between root and soil C:N ratio in the arboretum were weak, which may be due to the young age of the trees. With tree age, effects of tree chemical composition on soil chemistry, and vice versa, most likely increase.

Root and soil C:N ratios at the observational site were not significantly related. Soil abiotic properties at the observational site possibly overrode potential effects of tree chemical composition on soil causing the lack of relationship between plant compartments and soil.

\section{Drivers of microbial $\mathrm{C}$ and respiration}

Soil microbial properties differed considerably between the two sites with values mostly being higher at the observational site than at the arboretum suggesting that availability of microbial resources or/and edaphic conditions differed strongly between sites. This is likely due to the soil type at the observational site with its particular high proportion of soil organic matter (observational site: Haplic Chernozem, arboretum: Luvisol), and soil microbial biomass is known to correlate positively with soil organic matter content (Schnürer et al., 1985; Murphy et al., 2011).

Microbial basal respiration and microbial biomass were not affected by tree species identity. This is in contrast to other studies which found that contrasting characteristics of tree species, such as different litter quantity, litter chemistry, and chemical composition of rhizodeposits, drive distinct soil microbial community compositions underneath, directly and/or indirectly, e.g., via changes in soil $\mathrm{pH}$ and soil $\mathrm{C}$ and $\mathrm{N}$ concentrations (Ushio et al., 2008; Strickland et al., 2009). Due to the young age of the studied trees at both sites, tree litter and rhizodeposits may be of minor influence for microbial biomass being associated with roots. However, the specific respiratory quotient differed significantly among tree species suggesting different metabolic efficiency of the microbial community. Possibly, element use efficiency per se (Mooshammer et al., 2014; Zechmeister-Boltenstern et al., 2015) or even microbial community composition was altered with total microbial biomass remaining the same across tree species. Different studies documented the homeostatic nature of microorganisms in terms of $\mathrm{C}: \mathrm{N}$ ratios and, thus, the ability to regulate assimilation of $\mathrm{C}$ and $\mathrm{N}$ by releasing elements in excess and by the production of extracellular enzymes which may corroborate the former assumption (Cleveland and Liptzin, 2007; Xu et al., 2013; Zechmeister-Boltenstern et al., 2015). Similar to microbial biomass, soil C:N ratio was also not affected by tree species presumably due to the age of the trees.

All three soil microbial properties showed significant correlations with soil C:N ratios, whereas they did not significantly correlate with leaf $\mathrm{C}$ and $\mathrm{N}$ concentrations, root $\mathrm{C}$ and $\mathrm{N}$ concentrations, and leaf and root $\mathrm{C}: \mathrm{N}$ ratios. The results suggest that stoichiometry of soil but not that of plant tissue determined microbial properties in root-associated soil in the present study (Sterner and Elser, 2002). One site of our study is a tree plantation on former agricultural soil whose potentially high fertility may lead to a decoupling of plant traits and microbial activity and growth. Further, $\mathrm{C}$ and $\mathrm{N}$ concentrations measurements in our study 
were conducted with topsoil comprising a mixture of mineral soil and organic matter, a common food resource for soil microorganisms. A considerable part of the organic matter represents readily utilisable resources for microorganisms, such as rhizodeposits, that have not undergone different transformation processes (Kuzyakov and Larionova, 2005; Balasooriya et al., 2014). Senescing leaves, however, underwent different decomposition processes after entering the soil being driven by different primary decomposer groups that have different nutrient demands and abilities to break down material. This leads to substantial non-linear changes, mostly increases, in C:N ratios of the material (McGroddy et al., 2004). This may contribute to the relationships of plant tissue and soil with microbial biomass. Other studies confirmed the relation between the soil microbial community and their stoichiometry and C concentrations or C:N ratio of soil (Ushio et al., 2008; Murphy et al., 2011; Wan et al., 2015; Zechmeister-Boltenstern et al., 2015), but also point to the influence of tree species, i.e., the quality of plant tissue, on soil (Ushio et al., 2008).

Although mostly not significant, positive effects of soil C:N ratio on soil microbial properties were mainly driven by $\mathrm{C}$ concentrations rather than by $\mathrm{N}$ concentrations, suggesting C-limitation of the microbial community. Given the theory of homeostasis in organisms (Cleveland and Liptzin, 2007), microorganisms at our sites may not be able to decouple their $\mathrm{C}$ levels from that of soil. This is consistent with other studies that found linear relationships between microbial and soil C compared to microbial and soil $\mathrm{N}$ (Wardle, 1998; Heuck et al., 2015; Zechmeister-Boltenstern et al., 2015).

\section{Conclusions}

The results of this study suggest weak relationships of C:N ratios between plant aboveground and belowground tissues. Furthermore, microorganisms did not depend on the stoichiometry of these tissues. The early successional stage of the trees in the study as well as the potential influence of the prior agricultural use may have contributed to the weak relationships. However, soil stoichiometry may be a better predictor for soil microbial biomass and activity than plant stoichiometry. We showed this, for the first time, across a large variety of tree species and different sites with distinct soil properties. Still, further research is needed to get better insights into plant chemical traits (Tsunoda \& van Dam, this Special Issue) and their interactions between above- and belowground compartments as well as to make generalisations across different species and environments. Moreover, it is indispensable to disentangle element demands of different organisms to get a more comprehensive picture of stoichiometric constraints and, thus, the driving forces of the composition and functioning of ecosystems.

\section{Supplementary Material}

Refer to Web version on PubMed Central for supplementary material.

\section{Acknowledgements}

We acknowledge support by the European Research Council (ERC) under the European Union's Horizon 2020 research and innovation program (grant agreement no 677232) and the German Centre for Integrative Biodiversity Research (iDiv) Halle-Jena-Leipzig funded by the German Research Foundation (FZT 118). We thank two anonymous reviewers for helpful comment as well as Anja Kahl and Mario Liebergesell for giving the opportunity 
to sample the arboretum of the Leipzig University and general support. We thank Ines Hilke and Birgit Fröhlich from the Max Planck Institute for Biogeochemistry, Jena, Germany, for C and N measurements. Sincere thanks to Ulrich Pruschitzki for support during field and laboratory work. We further acknowledge the support of Andreas Sickert, head of the Leipzig forestry department, for facilitating the establishment of the ARBOfun functional diversity arboretum.

\section{References}

Aerts R, de Caluwe H. Nutritional and plant-mediated controls on leaf litter decomposition of Carex species. Ecology. 1997; 78:244-260.

Altermann M, Rinklebe J, Merbach I, Körschens M, Langer U, Hofmann B. Chernozem - Soil of the Year 2005. J Plant Nutr Soil Sci. 2005; 168:725-740.

Anderson JM, Domsch KH. A physiological method for the quantitative measurement of microbial biomass in soils. Soil Biol Biochem. 1978; 10:215-221.

Balasooriya WK, Denef K, Huygens D, Boeckx P. Translocation and turnover of rhizodeposit carbon within soil microbial communities of an extensive grassland ecosystem. Plant Soil. 2014; 376:6173.

Beck T, Joergensen RG, Kandeler E, Makeschin F, Nuss E, Oberholzer HR, Scheu S. An interlaboratory comparison of ten different ways of measuring soil microbial biomass C. Soil Biol Biochem. 1997; 29:1023-1032.

Bell C, Carrillo Y, Boot CM, Rocca JD, Pendall E, Wallenstein MD. Rhizosphere stoichiometry: are C: $\mathrm{N}$ : P ratios of plants, soils, and enzymes conserved at the plant species-level? New Phytol. 2014; 201:505-517. [PubMed: 24117992]

Birouste M, Kazakou E, Blanchard A, Roumet C. Plant traits und decomposition: are the relationships for roots comparable to those for leaves? Ann Bot. 2012; 109:463-472. [PubMed: 22143881]

Bradford MA, Keiser AD, Davies CA, Mersmann CA, Strickland MS. Empirical evidence that soil carbon formation from plant inputs is positively related to microbial growth. Biogeochemistry. 2013; 113:271-281.

Buchkowski RW, Schmitz OJ, Bradford MA. Microbial stoichiometry overrides biomass as a regulator of soil carbon and nitrogen cycling. Ecology. 2015; 96:1139-1149. [PubMed: 26230033]

Chaopricha NT, Marin-Spiotta E. Soil burial contributes to deep soil organic carbon storage. Soil Biol Biochem. 2014; 69:251-264.

Chen J, Stark JM. Plant species effects and carbon and nitrogen cycling in a sagebrush-crested wheatgrass soil. Soil Biol Biochem. 2000; 32:47-57.

Cleveland CC, Liptzin D. C:N:P stoichiometry in soil: is there a "Redfield ratio" for the microbial biomass? Biogeochemistry. 2007; 85:235-252.

Cornelissen JH, Lavorel CS, Garnier E, Díaz S, Buchmann N, Gurvich DE, Reich PB, ter Steege H, Morgan HD, van der Heijden MGA, Pausas JG, et al. A handbook of protocols for standardised und easy measurement of plant functional traits worldwide. Aust J Bot. 2003; 51:335-380.

Cortez J, Garnier E, Perez-Harguindeguy N, Debussche M, Gillon D. Plant traits, litter quality and decomposition in a Mediterranean old-field succession. Plant Soil. 2007; 296:19-34.

Craine JM, Lee WG, Bond WJ, Williams RJ, Johnson LC. Environmental constraints on a global relationship among leaf and root traits of grasses. Ecology. 2005; 86:12-19.

Cusack DF, Chou WW, Yang WH, Harmon ME, Silver WL, The LIDET Team. Controls on long-term root and leaf litter decomposition in neotropical forests. Glob Chang Biol. 2009; 15:1339-1355.

de Ruiter PC, Van Veen JA, Moore JC, Brussaard L, Hunt HW. Calculation of nitrogen mineralization in soil food webs. Plant Soil. 1993; 157:263-273.

de Vries FT, Manning P, Tallowin JRB, Mortimer SR, Pilgrim ES, Harrison KA, Hobbs PJ, Quirk H, Shipley B, Cornelissen JH, Kattge J, et al. Abiotic drivers and plant traits explain landscape-scale patterns in soil microbial communities. Ecol Lett. 2012; 15:1230-1239. [PubMed: 22882451]

Demoling F, Figueroa D, Baath E. Comparison of factors limiting bacterial growth in different soils. Soil Biol Biochem. 2007; 39:2485-2495.

Eisenhauer N, Reich PB. Above- and belowground inputs both fuel soil food webs. Soil Biol Biochem. 2012; 45:156-160. 
Elser JJ, Fagan WF, Denno RF, Dobberfuhl DR, Folarin A, Huberty A, Interlandi S, Kilham SS, McCauley E, Schulz KL, Siemann EH, et al. Nutritional constraints in terrestrial and freshwater food webs. Nature. 2000; 408:578-580. [PubMed: 11117743]

Fanin N, Fromin N, Buatois B, Hättenschwiler S. An experimental test of the hypothesis of nonhomeostatic consumer stoichiometry in a plant litter-microbe system. Ecol Lett. 2013; 16:764772. [PubMed: 23521784]

Farrell M, Prendergast-Miller M, Jones DL, Hill PW, Condron LM. Soil microbial organic nitrogen uptake is regulated by carbon availability. Soil Biol Biochem. 2014; 77:261-267.

Freschet GT, Cornelissen JHC, van Logtestijn RSP, Aerts R. Evidence of the 'plant economics spectrum' in a subarctic flora. J Ecol. 2010; 98:362-373.

Freschet GT, Cornwell WK, Wardle DA, Elumeeva TG, Liu W, Jackson BG, Onipchenko VG, Soudzilovskaia NA, Tao J, Cornelissen JHC. Linking litter decomposition of above- and belowground organs to plant-soil feedbacks worldwide. J Ecol. 2013; 101:943-952.

Hajek P, Hertel D, Leuschner C. Intraspecific variation in root and leaf traits and leaf-root trait linkages in eight aspen demes (Populus tremula and P. tremuloides). Front Plant Sci. 2013; 4:415. [PubMed: 24155751]

Hanson PJ, Edwards NT, Garten CT, Andrews JA. Separating root and soil microbial contributions to soil respiration: a review of methods and observations. Biogeochemistry. 2000; 48:115-146.

Hartman WH, Richardson CJ. Differential nutrient limitation of soil microbial biomass and metabolic quotients $\left(\mathrm{qCO}_{2}\right)$ : Is there a biological stoichiometry of soil microbes? PLoS ONE. 2013; 8:e57127. [PubMed: 23526933]

Heal, OW., Anderson, JM., Swift, MJ. Plant litter quality and decomposition: an historical overview. Driven by nature: plant litter quality and decomposition. Cadish, G., Giller, KE., editors. CAB International; Wallingford, UK: 1997. p. 3-33.

Heuck C, Weig A, Spohn M. Soil microbial biomass C:N:P stoichiometry and microbial use of organic phosphorus. Soil Biol Biochem. 2015; 85:119-129.

Hinsinger P, Bengough AG, Vetterlein D, Young IM. Rhizosphere: biophysics, biogeochemistry and ecological relevance. Plant Soil. 2009; 321:117-152.

Hobbie JE, Hobbie EA. Microbes in nature are limited by carbon and energy: the starving-survival lifestyle in soil and consequences for estimating microbial rates. Front Microbiol. 2013; 4:324. [PubMed: 24273534]

Hobbie SE. Nitrogen effects on litter decomposition: a five-year experiment in eight temperate grassland and forest sites. Ecology. 2008; 89:2633-2644. [PubMed: 18831184]

Hobbie SE, Oleksyn J, Eissenstat DM, Reich PB. Fine root decomposition rates do not mirror those of leaf litter among temperate tree species. Oecologia. 2010; 162:505-513. [PubMed: 19882174]

Jackson RB, Mooney HA, Schulze E-D. A global budget for fine root biomass, surface area, and nutrient contents. Proc Natl Acad Sci USA. 1997; 94:7362-7366. [PubMed: 11038557]

Hutsch BW, Augustin J, Merbach W. Plant rhizodeposition an important source for carbon turnover in soils. J Plant Nutr Soil Sci. 2000; 165:397-407.

King JS, Albaugh TJ, Allen HL, Buford M, Strain BR, Dougherty P. Below-ground carbon input to soil is controlled by nutrient availability und fine root dynamics in loblolly pine. New Phytol. 2002; 154:389-398.

Kuzyakov Y, Larionova AA. Root and rhizomicrobial respiration: a review of approaches to estimate respiration by autotrophic and heterotrophic organisms in soil. J Plant Nutr Soil Sci. 2005; 168:503-520.

Lal R. Soil carbon sequestration impacts on global climate change and food security. Science. 2004; 304:1623-1627. [PubMed: 15192216]

Lambers H, Mougel C, Jaillard B, Hinsinger P. Plant-microbe-soil interactions in the rhizosphere: an evolutionary perspective. Plant Soil. 2009; 321:83-115.

Luo Y, Su B, Currie WS, Dukes JS, Finzi A, Hartwig U, Hungate B, McMurtrie RE, Oren R, Parton WJ, Pataki DE, et al. Progressive nitrogen limitation of ecosystem responses to rising atmospheric carbon dioxide. Bioscience. 2004; 54:731-739. 
Maire V, Gross N, Pontes L, da S, Picon-Cochard C, Soussana J-F. Trade-off between root nitrogen acquisition and shoot nitrogen utilization across 13 co-occurring pasture grass species. Funct Ecol. 2009; 23:668-679.

Martiny JBH, Bohannan BJM, Brown JH, Colwell RK, Fuhrman JA, Green JL, Horner-Devine MC, Kane M, Krumins JA, Kuske CR, Morin PJ, et al. Microbial biogeography: putting microorganisms on the map. Nat Revs Microbiol. 2006; 4:102-112. [PubMed: 16415926]

McGroddy M, Daufresne T, Hedin E. Scaling of C:N:P stoichiometry in forests worldwide: implications of terrestrial Redfield-type ratios. Ecology. 2004; 85:2390-2401.

Mooshammer M, Wanek W, Zechmeister-Boltenstern S, Richter A. Stoichiometric imbalances between terrestrial decomposer communities and their resources: mechanisms and implications of microbial adaptations to their resources. Front Microbiol. 2014; 5:22. [PubMed: 24550895]

Murphy DV, Cookson WR, Braimbridge M, Marschner P, Jones DL, Stockdale EA, Abbott LK. Relationships between soil organic matter and the soil microbial biomass (size, functional diversity, and community structure) in crop and pasture systems in a semi-arid environment. Soil Res. 2011; 49:582-594.

Myrold, DD. Transformations of nitrogen. Principles and applications of soil microbiology. Sylvia, DM.Fuhrmann, JJ.Hartel, PG., Zuberer, DS., editors. Prentice-Hall; USA: 1999.

Newman GS, Hart SC. Nutrient covariance between forest foliage and fine roots. For Ecol Manage. 2006; 236:136-141.

Osone Y, Tateno M. Nitrogen absorption by roots as a cause of interspecific variations in leaf nitrogen concentration and photosynthetic capacity. Funct Ecol. 2005; 19:460-470.

Paterson E. Importance of rhizodeposition in the coupling of plant and microbial productivity. Eur J Soil Sci. 2003; 54:741-750.

Pollierer MM, Langel R, Körner C, Maraun M, Scheu S. The underestimated importance of belowground carbon input for forest soil animal food webs. Ecol Lett. 2007; 10:729-736. [PubMed: 17594428]

Pregitzer KS, DeForest JL, Burton AJ, Allen MF, Ruess RW, Hendrick RL. Fine Root Architecture of Nine North American Trees. Ecol Monogr. 2002; 72:293-309.

R Core Team. R: A language and environment for statistical computing. R Foundation for Statistical Computing; Vienna, Austria: 2014. https://www.R-project.org/

Reich PB. The world-wide 'fast-slow' plant economics spectrum: a traits manifesto. J Ecol. 2014; 102:275-301.

Reich PB, Oleksyn J, Modrzynski J, Mrozinski P, Hobbie SE, Eissenstat DM, Chorover J, Chadwick OA, Hale CM, Tjoelker MG. Linking litter calcium, earthworms and soil properties: a common garden test with 14 tree species. Ecol Lett. 2005; 8:811-818.

Scheu S. Automated measurement of the respiratory response of soil microcompartments - active microbial biomass in earthworm faeces. Soil Biol Biochem. 1992; 24:1113-1118.

Scheu S, Schaefer M. Bottom-up control of the soil macrofauna community in a beechwood on limestone: manipulation of food resources. Ecology. 1998; 79:1573-1585.

Schimel DS. Terrestrial ecosystems and the carbon-cycle. Glob Chang Biol. 1995:77-91.

Schimel JP, Weintraub MN. The implications of exoenzyme activity on microbial carbon and nitrogen limitation in soil: a theoretical model. Soil Biol Biochem. 2003; 35:549-563.

Schnürer J, Clarholm M, Rosswall T. Microbial biomass and activity in an agricultural soil with different organic-matter contents. Soil Biol Biochem. 1985; 17:611-618.

Silver WL, Miya RK. Global patterns in root decomposition: comparisons of climate and litter quality effects. Oecologia. 2001; 129:407-419. [PubMed: 28547196]

Sterner, RW., Elser, JJ. Ecological stoichiometry: the biology of elements from molecules to the biosphere. Princeton University Press; USA: 2002.

Strickland MS, Osburn E, Lauber C, Fierer N, Bradford MA. Litter quality is in the eye of the beholder: initial decomposition rates as a function of inoculum characteristics. Funct Ecol. 2009; 23:627-636.

Swift, MJ., Heal, OW., Anderson, JM. Decomposition in terrestrial ecosystems. University of California Press; Berkeley, USA: 1979. 
Tempest DW, Neijssel OM. Physiological and energetic aspects of bacterial metabolite overproduction. FEMS Microbiol Lett. 1992; 100:169-176. [PubMed: 1478453]

Tsunoda T, van Dam NM. Root chemical traits and their roles in belowground biotic interactions. Under review for the same Special Issue.

Tjoelker MG, Craine JM, Wedin D, Reich PB, Tilman D. Linking leaf and root trait syndromes among 39 grassland and savannah species. New Phytol. 2005; 167:493-508. [PubMed: 15998401]

Ushio M, Wagai R, Balser TC, Kitayama K. Variations in the soil microbial community composition of a tropical montane forest ecosystem: Does tree species matter? Soil Biol Biochem. 2008; 40:2699_ 2702.

van der Heijden MGA, Bardgett RD, van Straalen NM. The unseen majority: soil microbes as drivers of plant diversity and productivity in terrestrial ecosystems. Ecol Lett. 2008; 11:296-310. [PubMed: 18047587]

Vance ED, Chapin FS. Substrate limitations to microbial activity in taiga forest floors. Soil Biol Biochem. 2001; 33:173-188.

Vitousek PM, Aber JD, Howarth RW, Likens GE, Matson PA, Schindler DW, Schlesinger WH, Tilman DG. Human alteration of the global nitrogen cycle: Sources and consequences. Ecol Appl. 1997; 7:737-750.

von Liebig, J. Die organische Chemie in ihrer Anwendung auf Agrikultur und Physiologie. Friedrich Vieweg und Sohn Publ. Co.; Braunschweig, Germany: 1840.

Wan X, Huang Z, He Z, Yu Z, Wang M, Davis MR, Yang Y. Soil C:N ratio is the major determinant of soil microbial community structure in subtropical coniferous and broadleaf forest plantations. Plant Soil. 2015; 387:103-116.

Wang J, Shen J, Wu Y, Tu C, Soininen J, Stegen JC, He J, Liu X, Zhang L, Zhang E. Phylogenetic beta diversity in bacterial assemblages across ecosystems: deterministic versus stochastic processes. ISME J. 2013; 7:1310-1321. [PubMed: 23446837]

Wardle D. A comparative assessment of factors which influence microbial biomass carbon and nitrogen levels in soil. Biol Rev. 1992; 67:321-358.

Wardle DA. Controls of temporal variability of the soil microbial biomass: a global-scale synthesis. Soil Biol Biochem. 1998; 30:1627-1637.

Wardle DA, Bardgett RD, Klironomos JN, Setälä H, van der Putten WH, Wall DH. Ecological linkages between aboveground and belowground biota. Science. 2004; 304:1629-1633. [PubMed: 15192218]

Xu X, Thornton PE, Post WM. A global analysis of soil microbial biomass carbon, nitrogen and phosphorus in terrestrial ecosystems. Glob Ecol Biogeogr. 2013; 22:737-749.

Zechmeister-Boltenstern S, Keiblinger KM, Mooshammer M, Peñuelas J, Richter A, Sardans J, Wanek W. The application of ecological stoichiometry to plant-microbial-soil organic matter transformations. Ecol Monogr. 2015; 85:133-155. 
(a)

(b)

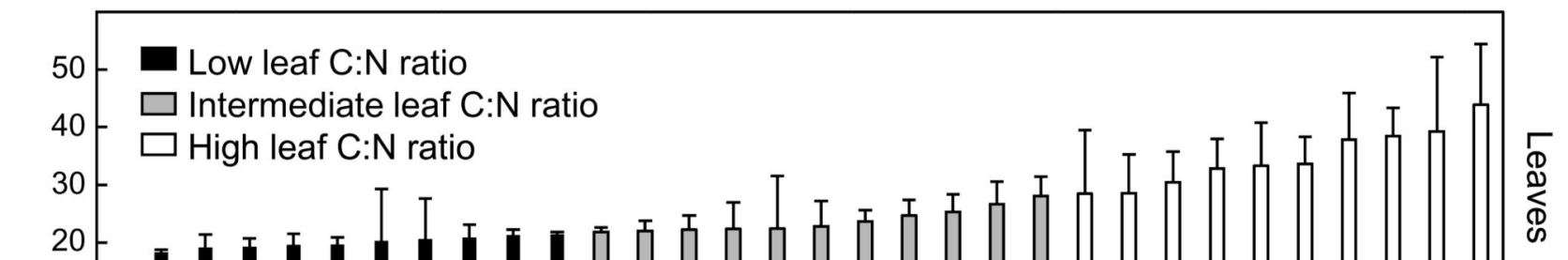

(c)

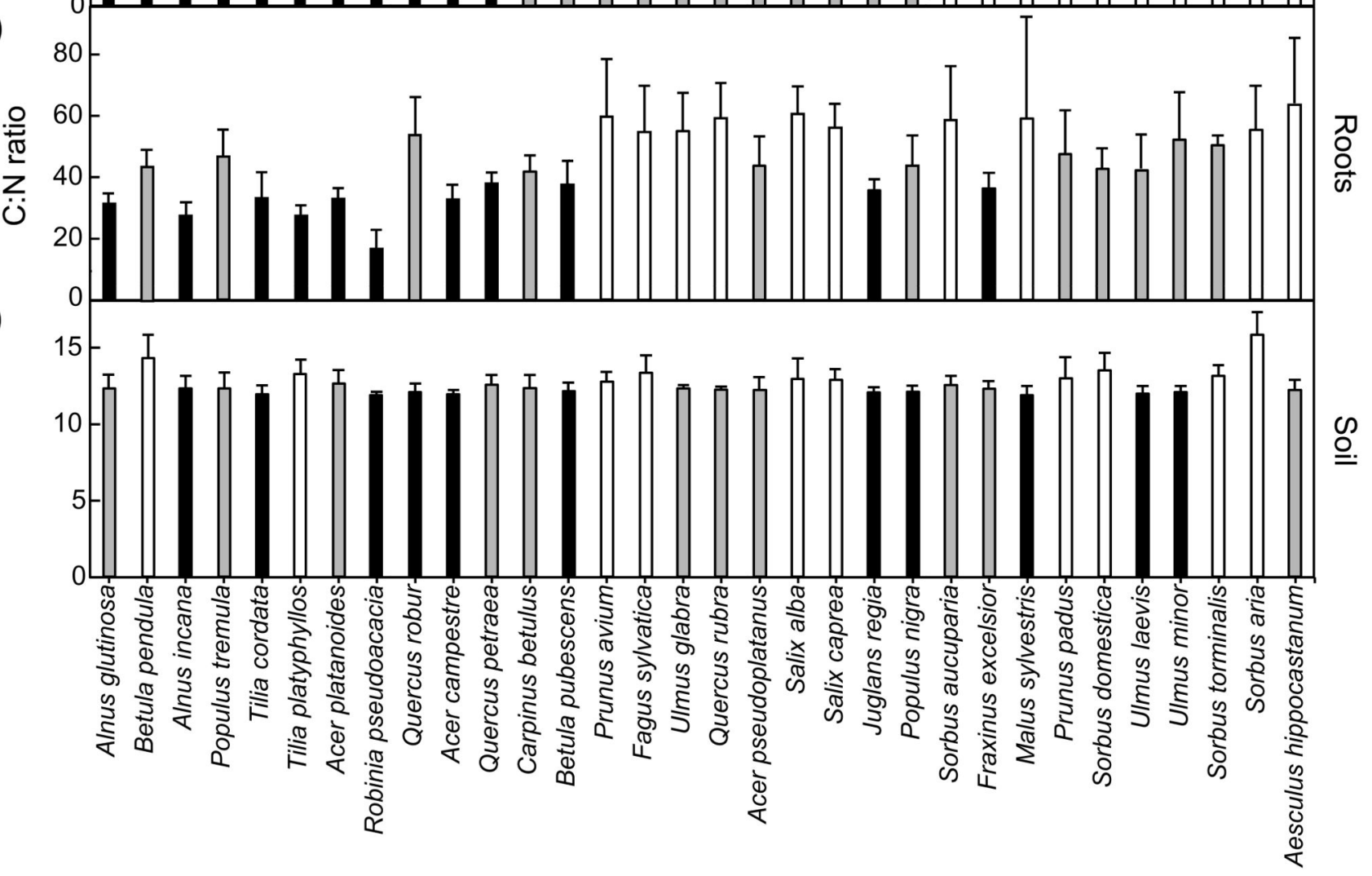

Fig. 1.

$\mathrm{C}: \mathrm{N}$ ratios of tree leaves, tree roots, and soil from the tree root region in the arboretum. Species are presented in the order of increasing leaf $\mathrm{C}: \mathrm{N}$ ratio. Colours of bars indicate low, intermediate, or high leaf C:N ratio. Error bars represent $95 \%$ confidence intervals. 
(a)

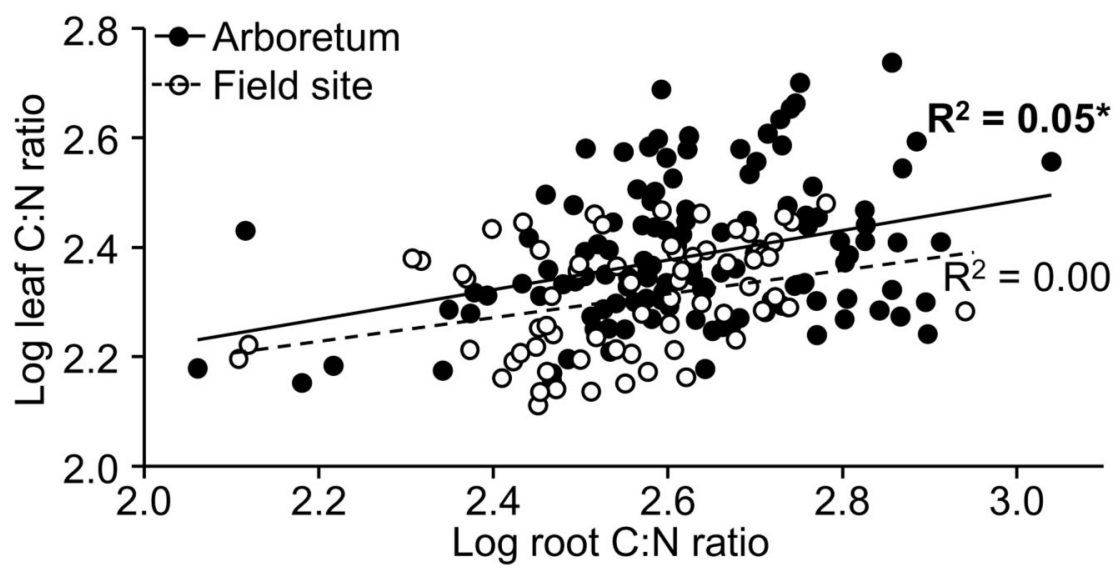

(b)

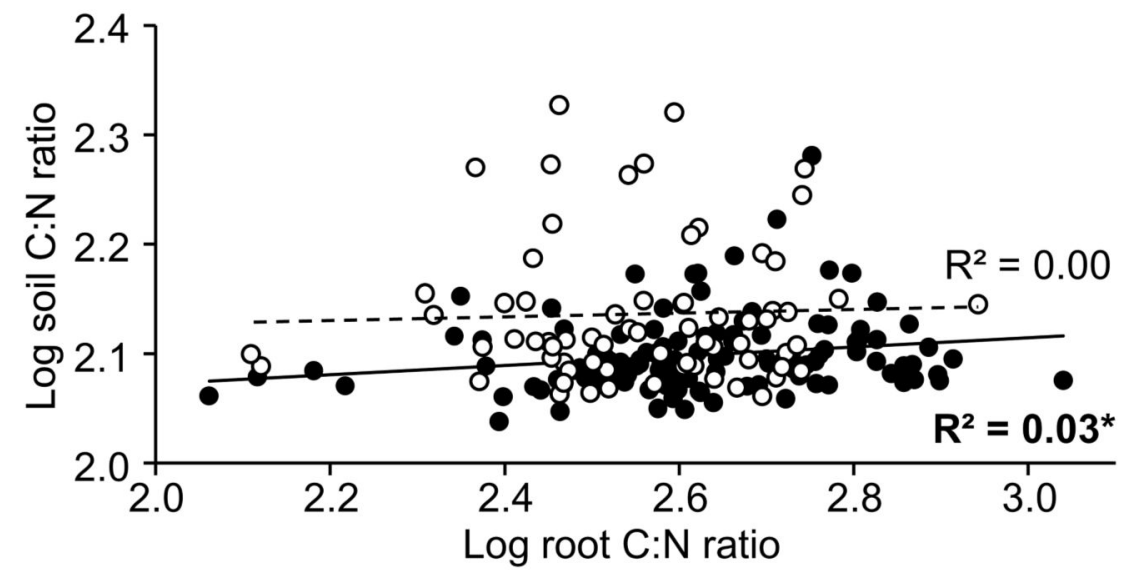

(c)

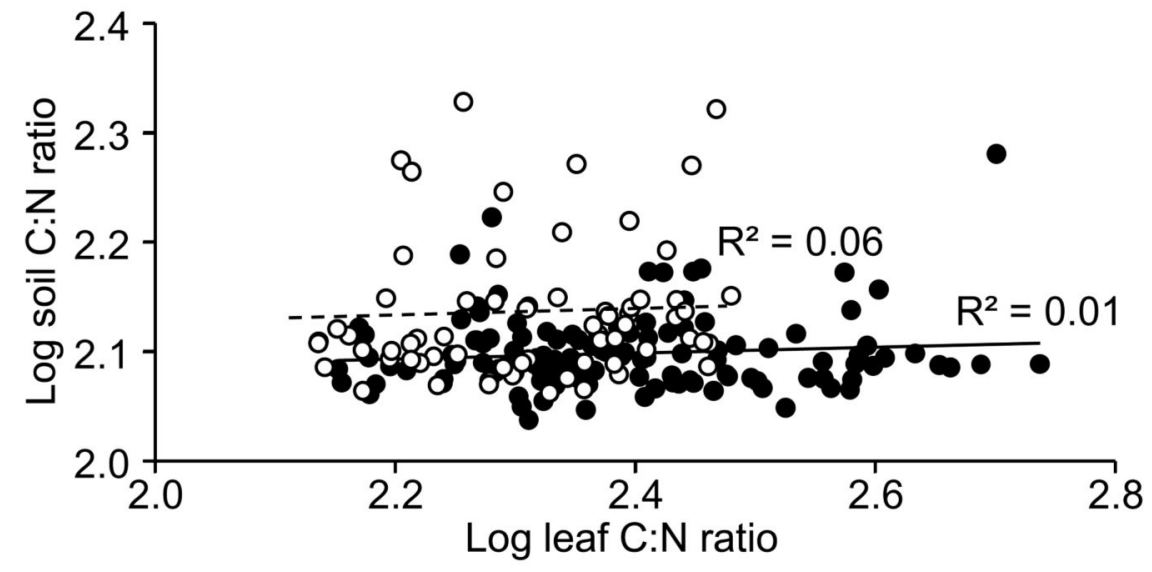

Fig. 2.

Linear regression of log-transformed C:N ratios of (a) tree roots and leaves, (b) tree roots and soil, and (c) tree leaves and soil at the two sites. Significant effects are given in bold. * stands for $\mathrm{P}<0.05$. 


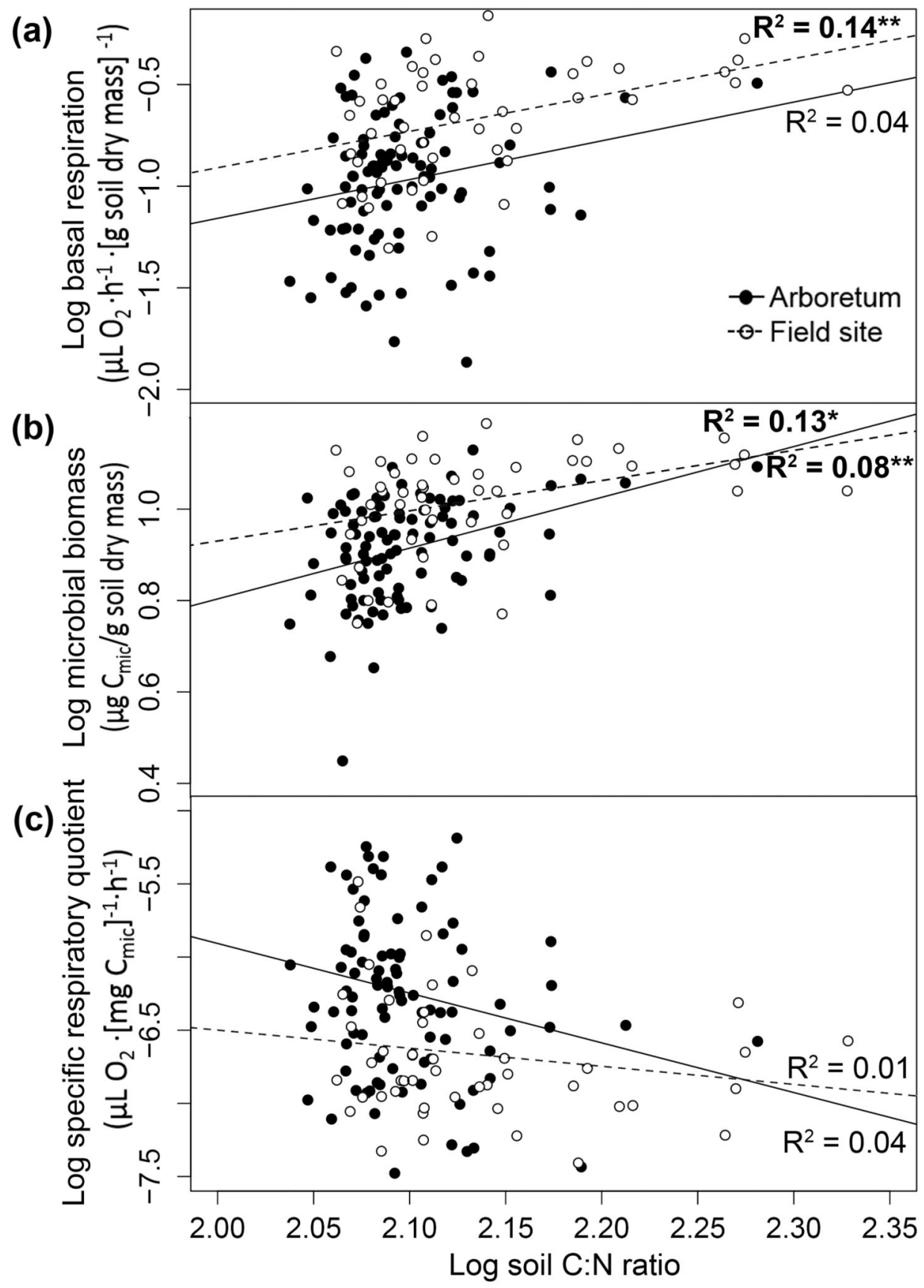

Fig. 3.

Linear regression between log-transformed soil C:N ratios and log-transformed (a) microbial basal respiration, (b) microbial biomass, and (c) specific respiratory quotient at the two sites. Significant effects are given in bold. * stands for $\mathrm{P}<0.05, * *$ stands for $\mathrm{P}<0.01$. 


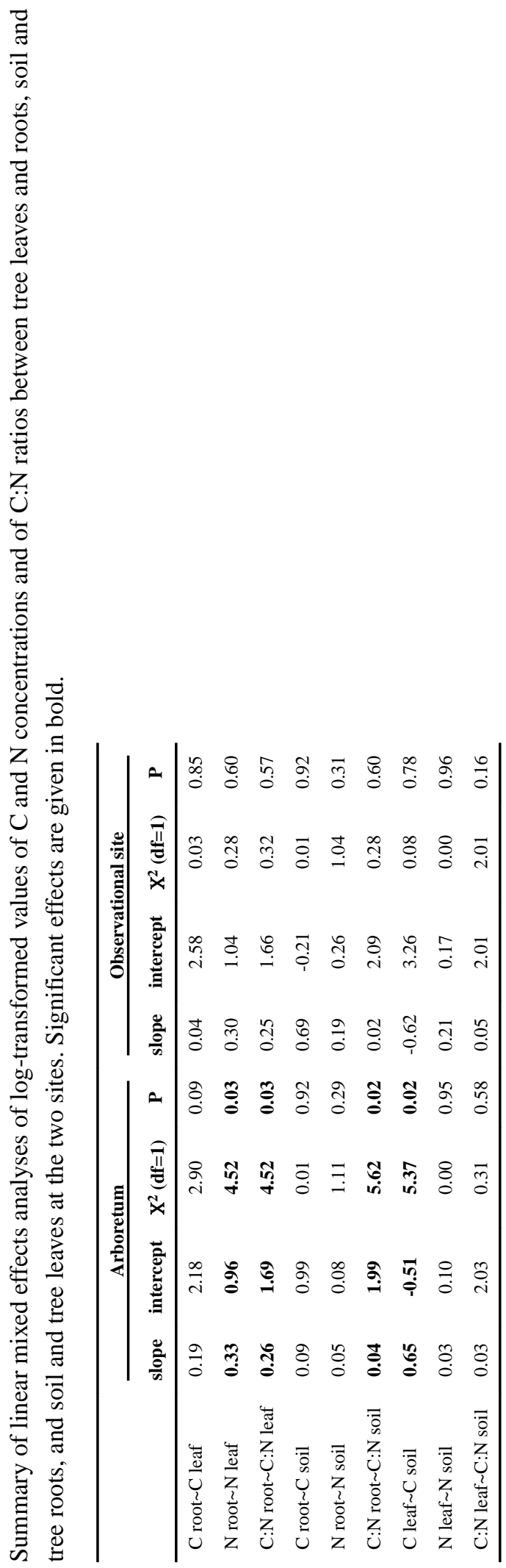




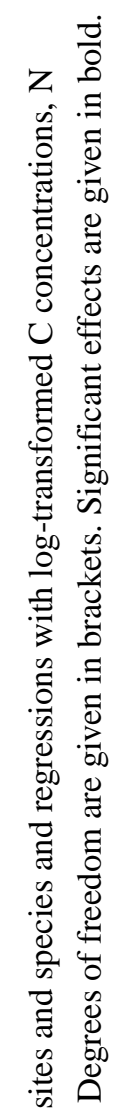

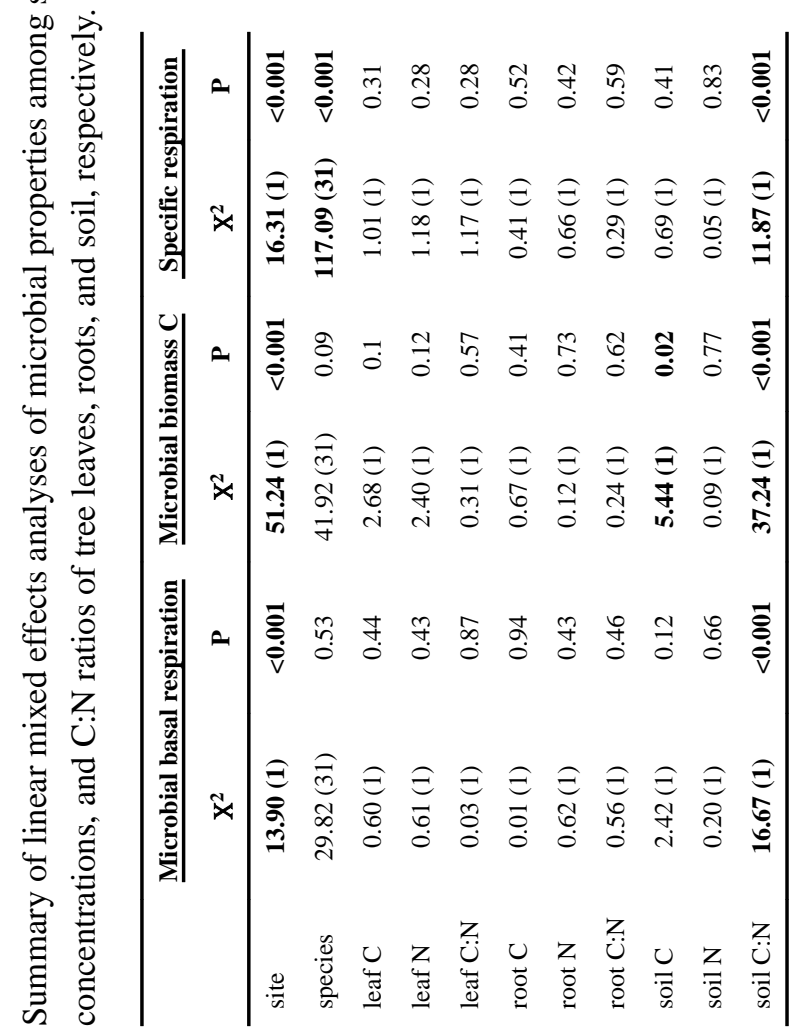

